\title{
Equatorial transport as diagnosed from nitrous oxide variability
}

\author{
P. Ricaud ${ }^{1}$, J.-P. Pommereau ${ }^{2}$, J.-L. Attié ${ }^{1,3}$, E. Le Flochmoën ${ }^{1}$, L. El Amraoui ${ }^{3}$, H. Teyssèdre ${ }^{3}$, V.-H. Peuch ${ }^{3}$, \\ W. Feng ${ }^{4}$, and M. P. Chipperfield ${ }^{4}$ \\ ${ }^{1}$ Université de Toulouse, Laboratoire d'Aérologie, CNRS UMR 5560, Toulouse, France \\ ${ }^{2}$ Université de Versailles St Quentin, LATMOS, CNRS UMR 8190, Verrières-Le-Buisson, France \\ ${ }^{3}$ CNRM, Météo-France, Toulouse, France \\ ${ }^{4}$ School of Earth and Environment, University of Leeds, Leeds, UK
}

Received: 11 December 2008 - Published in Atmos. Chem. Phys. Discuss.: 24 February 2009

Revised: 4 September 2009 - Accepted: 16 October 2009 - Published: 2 November 2009

\begin{abstract}
The mechanisms of transport on annual, semiannual and quasi-biennial time scales in the equatorial $\left(10^{\circ} \mathrm{S}-10^{\circ} \mathrm{N}\right)$ stratosphere are investigated using the nitrous oxide $\left(\mathrm{N}_{2} \mathrm{O}\right)$ measurements of the space-borne ODIN SubMillimetre Radiometer from November 2001 to June 2005, and the simulations of the three-dimensional chemical transport models MOCAGE and SLIMCAT. Both models are forced with analyses from the European Centre for Mediumrange Weather Forecast, but the vertical transport is derived either from the forcing analyses by solving the continuity equation (MOCAGE), or from diabatic heating rates using a radiation scheme (SLIMCAT). The $\mathrm{N}_{2} \mathrm{O}$ variations in the mid-to-upper stratosphere at levels above $32 \mathrm{hPa}$ are generally well captured by the models though significant differences appear with the observations as well as between the models, attributed to the difficulty of capturing correctly the slow upwelling associated with the Brewer-Dobson circulation. However, in the lower stratosphere, below $32 \mathrm{hPa}$, the observed variations are shown to be mainly seasonal with peak amplitude at $400-450 \mathrm{~K}(\sim 17.5-19 \mathrm{~km})$, totally missed by the models. The minimum $\mathrm{N}_{2} \mathrm{O}$ in June, out of phase by two months with the known minimum seasonal upwelling associated with the Brewer-Dobson circulation and moreover amplified over the Western Pacific compared to Africa is incompatible with the seasonal change of upwelling evoked to explain the $\mathrm{O}_{3}$ annual cycle in the same altitude range (Randel et al., 2007). Unless the $1.5 \mathrm{ppbv}$ amplitude of $\mathrm{N}_{2} \mathrm{O}$ annual cycle in the upper troposphere is totally wrong, the explanation of the observed $\mathrm{N}_{2} \mathrm{O}$ annual cycle of $15 \mathrm{ppbv}$ in the lower stratosphere requires another mechanism. A possible candidate for that might be the existence of a downward time-averaged mass flux above specific regions, as shown by
\end{abstract}

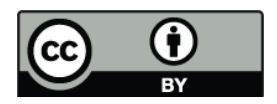

Correspondence to: P. Ricaud (philippe.ricaud@aero.obs-mip.fr)
Sherwood (2000) over Indonesia, required for compensating the energy sink resulting from the deep overshooting of cold and heavy air at high altitude over intense convective areas. But, since global models do currently not capture this subsidence, it must be recognised that a full explanation of the observations cannot be provided for the moment. However, the coincidence of the peak contrast between the Western Pacific and Africa with the maximum overshooting volume in May reported by the Tropical Rainfall Measuring Mission (TRMM) Precipitation Radar, suggests a strong influence of deep convection on the chemical composition of the tropical lower stratosphere up to $500 \mathrm{~K}(21 \mathrm{~km})$.

\section{Introduction}

Nitrous oxide $\left(\mathrm{N}_{2} \mathrm{O}\right)$ is an excellent tracer of atmospheric vertical transport since its sources are located in the troposphere (soils, wetlands, biomass burning and industrial emissions) where its lifetime is around 100 years. Its sink is in the stratosphere essentially by photolysis and reaction with electronically-excited oxygen atoms $\mathrm{O}\left({ }^{1} \mathrm{D}\right)$, the primary source of stratospheric odd nitrogen $\left(\mathrm{NO}_{\mathrm{y}}\right)$ (e.g. Brasseur et al., 1999), where its lifetime decreases from $\sim 1$ century in the lower stratosphere to $\sim 1$ month in the upper stratosphere around $45 \mathrm{~km}$. It is also a greenhouse gas which contributes to climate change (IPCC, 2001). After entering the stratosphere at the tropical tropopause, $\mathrm{N}_{2} \mathrm{O}$, like all longlived species, is transported by the Brewer-Dobson circulation to high altitudes and then to the polar latitudes. Its spatial and temporal distribution can be thus used as a diagnostic of global-scale transport processes at different timescales, from seasons to decades.

In the mid and upper stratosphere, due to its long lifetime, the equatorial $\mathrm{N}_{2} \mathrm{O}$ fields exhibit a strong semi-annual

Published by Copernicus Publications on behalf of the European Geosciences Union. 
oscillation (SAO), as shown by Randel et al. (1994) from two years of Cryogenic Limb Array Etalon Spectrometer (CLAES) observations. This behaviour was recently confirmed by Jin et al. (2009) from the measurements of the Microwave Limb Sounder (MLS) on the AURA platform, the Atmospheric Chemistry Experiment Fourier Transform Spectrometer (ACE-FTS) and the Sub-Millimetre Radiometer (SMR) aboard ODIN. Furthermore, combining $\mathrm{N}_{2} \mathrm{O}$ from CLAES in 1991-1993 (O'Sullivan and Dunkerton, 1997), $\mathrm{CH}_{4}$, and $\mathrm{H}_{2} \mathrm{O}$ from the Halogen Occultation Experiment (HALOE) on the Upper Atmosphere Research Satellite (UARS) and $\mathrm{O}_{3}$ from the Stratospheric Aerosol and Gas Experiment II (SAGE II) on the Earth Radiation Budget Experiment (ERBE), Randel and Wu (1996) and Baldwin et al. (2001) demonstrated the influence of the quasi-biennial oscillation (QBO) on the distribution of long-lived species in the equatorial belt.

At lower altitude in the tropical upper troposphere-lower stratosphere (UTLS), several studies based on satellite observations of $\mathrm{O}_{3}, \mathrm{~N}_{2} \mathrm{O}, \mathrm{HCl}, \mathrm{H}_{2} \mathrm{O}, \mathrm{HF}$ and $\mathrm{CH}_{4}$ from UARS/HALOE and AURA/MLS, together with ozonesondes, have shown the influence of the annual oscillation (AO) and the QBO (Randel et al., 2007; Schoeberl et al., 2008), whilst Gettelman et al. (2004) explored the impact of the Asian monsoon during the June-August period. Finally, Ricaud et al. (2007) from a combination of ODIN $\mathrm{N}_{2} \mathrm{O}$, HALOE $\mathrm{CH}_{4}$ and MLS CO observations have shown the large variations of species concentrations in the equatorial low stratosphere in March-April-May (MAM), displaying marked maxima over Africa and other land areas, very consistent with the overshooting picture derived from the Tropical Rainfall Measuring Mission (TRMM) Precipitation Radar (Liu and Zipser, 2005).

As an extension of the previous study, here we investigate how $\mathrm{N}_{2} \mathrm{O}$ behaves over a five-year period in the entire equatorial stratosphere including the Tropical Tropopause Layer (TTL), the region of intermediate lapse rate extending from the level of zero net radiative heating (LZH) $(\sim 14 \mathrm{~km}, \sim 150 \mathrm{hPa})$ to the level of stratospheric lapse rate $(\sim 18.5 \mathrm{~km}, \sim 70 \mathrm{hPa})$. We have combined ODIN/SMR measurements from 2001 to 2006 and long-term runs of the three-dimensional (3-D) chemical transport models (CTMs) SLIMCAT and MOCAGE. Particular attention has been paid to the UTLS to see how the contrast between land and oceanic regions observed by Ricaud et al. (2007) in MAM 2002-2004, extends to other seasons.

Information on the ODIN $\mathrm{N}_{2} \mathrm{O}$ observations and model simulations are provided in Sect. 2. Section 3 is devoted to the presentation of the time evolution of $\mathrm{N}_{2} \mathrm{O}$ in the stratosphere from November 2001 to June 2005 in the equatorial belt and the influence of annual, semi-annual and quasibiennial oscillations. Section 4 concentrates on the annual oscillation in the lower stratosphere and its possible explanations. Section 5 summarises the findings.

\section{Observations and models}

\subsection{ODIN}

The data used here are from the ODIN/SMR instrument. The ODIN mini-satellite (Murtagh et al., 2002) was placed into a $600-\mathrm{km}$ sun-synchronous, terminator orbit in February 2001 and is still operational. The platform includes the SMR microwave instrument (Frisk et al., 2003) that can measure $\mathrm{O}_{3}, \mathrm{ClO}, \mathrm{N}_{2} \mathrm{O}, \mathrm{HNO}_{3}, \mathrm{H}_{2} \mathrm{O}$, and $\mathrm{CO}$ in the frequency domain $480-580 \mathrm{GHz}$, most of its measurements being validated (e.g. Barret et al., 2006). The present study is based on the retrievals of the $502.296-\mathrm{GHz} \mathrm{N} \mathrm{N}_{2} \mathrm{O}$ line using the Optimal Estimation Method (Rodgers, 2000). On average, $\mathrm{N}_{2} \mathrm{O}$ measurements are performed one day out of three, due to sharing of the instrument with astronomy. All measurements performed between November 2001 and July 2005 have been analyzed using version V222 of the retrieval algorithm (Urban et al., 2005). Note that from November 2005 to October 2006 , ODIN $\mathrm{N}_{2} \mathrm{O}$ data have been processed using version V225 of the retrieval algorithm but these data are not used in the present analysis that only covers November 2001-June 2005. The vertical resolution is $2 \mathrm{~km}$. The single-scan precision ranges from 10 to $45 \mathrm{ppbv}$ for $\mathrm{N}_{2} \mathrm{O}$ mixing ratios varying from 0 to $325 \mathrm{ppbv}$. The total systematic error varies from 3 to $35 \mathrm{ppbv}$ for $\mathrm{N}_{2} \mathrm{O}$ mixing ratios from 0 to $>150 \mathrm{ppbv}$. In the UTLS, the single scan precision is $\sim 39$ and $\sim 24 \mathrm{ppbv}$ $(\sim 10-12 \%)$ at $100 \mathrm{hPa}$ and $70 \mathrm{hPa}$, respectively and the total systematic error is $\sim 22$ and $\sim 13 \mathrm{ppbv}$ ( $\sim 4-6 \%$ ), respectively. All measurements have been averaged into bins of $10^{\circ}$ latitude $\times 30^{\circ}$ longitude. Typically, for one-month averages, the precision per bin in the latitude band $10^{\circ} \mathrm{S}-10^{\circ} \mathrm{N}$ is ranging $0.8-7.0 \mathrm{ppbv}$ at $100 \mathrm{hPa}, 0.8-2.0 \mathrm{ppbv}$ at $70 \mathrm{hPa}$ and $0.35-1.00 \mathrm{ppbv}$ at $10 \mathrm{hPa}$. Several analyses have been performed in this study, either zonal averages within $10^{\circ} \mathrm{S}-$ $10^{\circ} \mathrm{N}$ from 2001 to 2005 , or monthly mean during the 20012005 period within the whole $10^{\circ} \mathrm{S}-10^{\circ} \mathrm{N}$ zonal band, or limited to the African and Western Pacific sectors. The precision of these averaged data is thus improved to $\sim 0.2-1.2$, $\sim 0.2-0.4$ and $\sim 0.07-0.20 \mathrm{ppbv}$ at 100,70 and $10 \mathrm{hPa}$, respectively.

\subsection{SLIMCAT}

SLIMCAT is an off-line 3-D CTM described in detail in Chipperfield (1999). The model uses a hybrid $\sigma-\theta$ vertical coordinate and extends from the surface to a top level which depends on the domain of the forcing analyses. Vertical advection in the $\theta$-level domain (above $350 \mathrm{~K}$ ) is calculated from diabatic heating rates using a radiation scheme which gives a better representation of vertical transport and age-ofair even with European Centre for Medium-range Weather Forecasts (ECMWF) ERA40 analyses than using vertical winds derived from the analyses which have known problems (Chipperfield, 2006). The model contains a detailed 
Table 1. Correlation coefficients between ODIN, SLIMCAT and MOCAGE $\mathrm{N}_{2} \mathrm{O}$ and ECMWF zonal wind speed $(u)$ in the Equatorial band $\left(10^{\circ} \mathrm{S}-10^{\circ} \mathrm{N}\right)$ from 100 to $1 \mathrm{hPa}$.

\begin{tabular}{cccc}
\hline \multirow{2}{*}{ Pressure $(\mathrm{hPa})$} & \multicolumn{3}{c}{ Correlation coefficient: $\mathrm{N}_{2} \mathrm{O}$ vs. $u$} \\
& ODIN & SLIMCAT & MOCAGE \\
\hline 100 & 0.25 & 0.73 & 0.17 \\
46 & -0.26 & -0.23 & -0.67 \\
21 & -0.60 & -0.36 & -0.34 \\
10 & -0.74 & -0.55 & -0.55 \\
4.6 & -0.62 & -0.58 & -0.75 \\
2.1 & -0.66 & -0.58 & -0.68 \\
1 & -0.71 & -0.63 & -0.60 \\
\hline
\end{tabular}

stratospheric chemistry scheme. The present experimental set up is detailed in Feng et al. (2007). The horizontal resolution is $7.5^{\circ} \times 7.5^{\circ}$ with 24 levels from the surface to about $60 \mathrm{~km}$. The model was forced using the 6-hourly 60-level ECMWF analyses from January 1977 to June 2005. From 1 January 1977 to 31 December 2001 the standard ERA-40 product is used (Uppala et al., 2005), and after this date, the operational analyses are employed. In the run used here there is no explicit treatment of tropospheric convection. The troposphere is assumed well mixed, i.e. tropospheric trace gases are mixed with a constant volume mixing ratio profile up to the tropopause $(380 \mathrm{~K}$ in the tropics). The modelled ozone field is used in the calculation of diabatic heating. The longterm time evolution of global surface mixing ratios of greenhouse gases (particularly $\mathrm{N}_{2} \mathrm{O}$ ) is prescribed according to the Intergovernmental Panel on Climate Change (IPCC) recommendations (IPCC, 2001). Therefore, as SLIMCAT assumes a well-mixed troposphere there are no seasonal variations in $\mathrm{N}_{2} \mathrm{O}$ in the model UT. Furthermore, the model run covers the period 1977-2005 for studying the long-term evolution of $\mathrm{N}_{2} \mathrm{O}$ but only equatorial $\left(10^{\circ} \mathrm{S}-10^{\circ} \mathrm{N}\right)$ zonally-averaged $\mathrm{N}_{2} \mathrm{O}$ data from November 2001 to June 2005 are used in the present study.

\subsection{MOCAGE}

MOCAGE-Climat (Teyssèdre et al., 2007) is the climate version of Météo-France's tropospheric-stratospheric MOCAGE 3-D CTM. The climate version used in this study has 60 layers from the surface up to $0.07 \mathrm{hPa}$, with a horizontal resolution of $5.6^{\circ} \times 5.6^{\circ}$. MOCAGE is forced by ECMWF operational 6-hourly analyses during the full period from 1 January 2000 to 31 December 2005, i.e., the same as SLIMCAT but after January 2002 only. Indeed, as explained above, prior to that date SLIMCAT is using the standard ERA-40 products. MOCAGE uses a semi-Lagrangian advection scheme and vertical velocities are recalculated from the forcing analyses by solving continuity equation. MOCAGEClimat contains a detailed tropospheric-stratospheric chem-
Table 2. Same as Table 1 but for ECMWF vertical wind $(\Omega)$.

\begin{tabular}{cccc}
\hline Pressure $(\mathrm{hPa})$ & \multicolumn{3}{c}{ Correlation coefficient: $\mathrm{N}_{2} \mathrm{O}$ vs. $\Omega$} \\
& ODIN & SLIMCAT & MOCAGE \\
\hline 100 & 0.11 & 0.69 & -0.05 \\
46 & 0.19 & 0.31 & 0.61 \\
21 & 0.66 & -0.05 & 0.59 \\
10 & 0.56 & 0.50 & 0.59 \\
4.6 & 0.53 & 0.22 & 0.37 \\
2.1 & 0.56 & 0.38 & 0.54 \\
1 & 0.37 & 0.37 & 0.32 \\
\hline
\end{tabular}

istry scheme. Initial chemical conditions were taken from a previous simulation to allow the model to quickly reach its numerical equilibrium, especially for long-lived species, such as $\mathrm{N}_{2} \mathrm{O}$. Surface emissions prescribed in MOCAGEClimat are based upon yearly- or monthly-averaged climatology. The $\mathrm{N}_{2} \mathrm{O}$ surface emissions are taken from the Global Emissions Inventory Activity and representative of the year 1990 (Bouwman et al., 1995). They include anthropogenic and biogenic sources, for a total emission rate of $14.7 \mathrm{Tg}$ (N) $\mathrm{yr}^{-1}$. The mean tropospheric $\mathrm{N}_{2} \mathrm{O}$ is constrained in MOCAGE to an average value of 316 ppbv over the 2000 2005 period whilst in SLIMCAT it increases from $315.6 \mathrm{ppbv}$ in January 2000 to 320.5 ppbv in December 2005.

Regarding convection, the present run was performed using the scheme of Betchold et al. (2001) that allows overshooting and transport of material into the stratosphere. However, given its coarse $\left(5.6^{\circ} \times 5.6^{\circ}\right)$ resolution, MOCAGE can hardly capture overshooting across the tropopause. Indeed, as shown by Ricaud et al. (2007) for the period of MAM 2002-2004, the probability density function of altitude reached by convection in MOCAGE is negligible above $150 \mathrm{hPa}$ within $10^{\circ} \mathrm{S}-10^{\circ} \mathrm{N}$ whatever the area considered: Africa, South America or Western Pacific. In this study, the modelled data have been averaged into bins of $10^{\circ}$ latitude $\times 30^{\circ}$ longitude over the period November 2001-June 2005. More information can be found in Ricaud et al. (2007).

\section{Influence of transport on the $\mathrm{N}_{2} \mathrm{O}$ stratospheric distribution}

The $\mathrm{N}_{2} \mathrm{O}$ anomaly, defined as the difference between the $\mathrm{N}_{2} \mathrm{O}$ field and its mean and linear trend over the period, in the ODIN, MOCAGE and SLIMCAT data sets during the period 2000-2006 from 100 to $1 \mathrm{hPa}$ is shown in Fig. 1, onto which the ECMWF zonal wind $u$ is superimposed. Easterlies (westerlies) are represented by solid (dashed) lines. The vertical distributions of the amplitude of the AO, SAO and QBO during the November 2001-June 2005 overlapping period derived from these data are shown in Fig. 2 as a function of pressure. The amplitude of each was derived using a 


\section{Equatorial Band $\left(10^{\circ} \mathrm{S}-10^{\circ} \mathrm{N}\right)$}
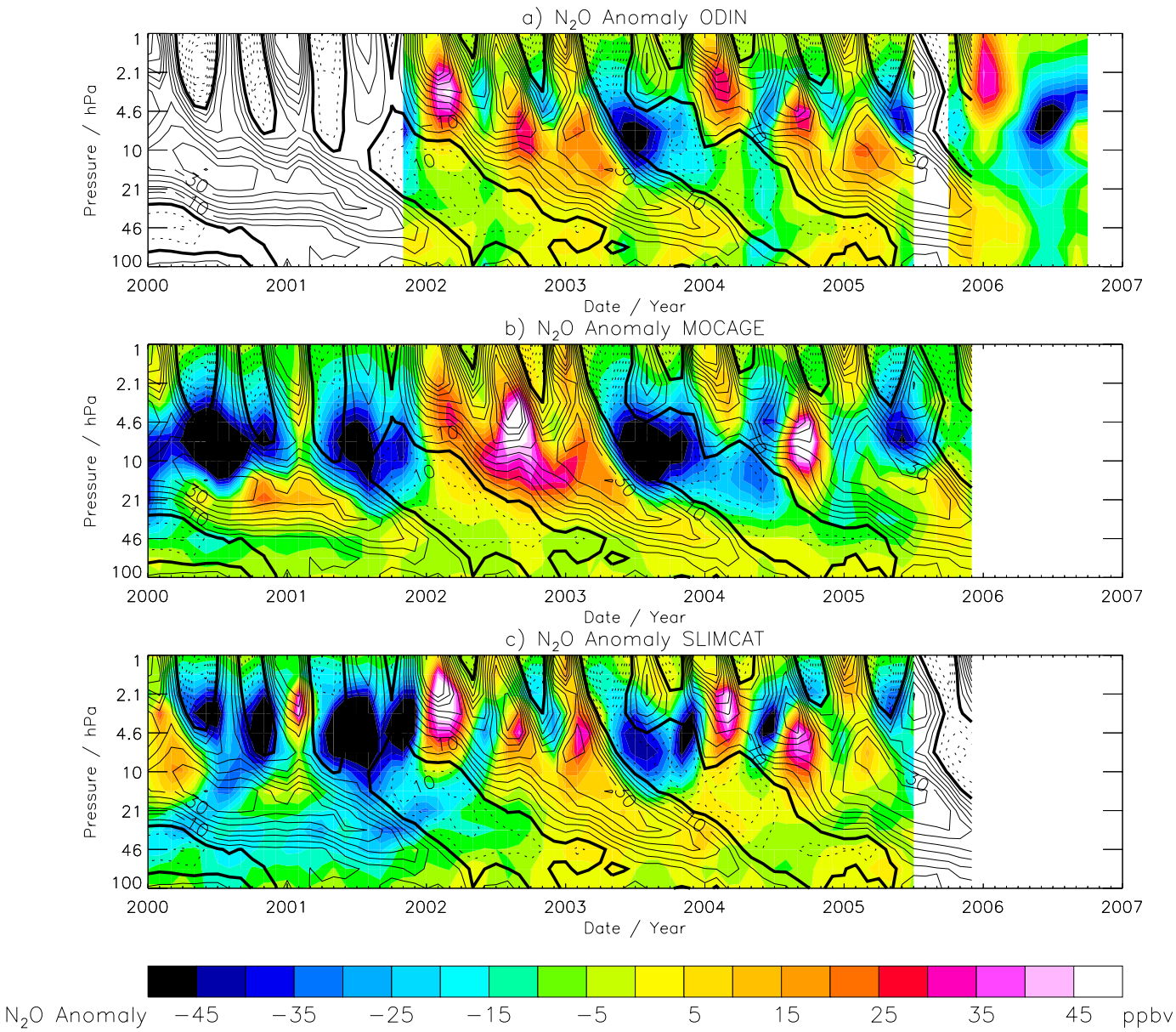

Fig. 1. $\mathrm{N}_{2} \mathrm{O}$ anomaly $\left(\mathrm{N}_{2} \mathrm{O}\right.$ minus detrended $2000-2006$ average) within $10^{\circ} \mathrm{S}-10^{\circ} \mathrm{N}$. From top to bottom: ODIN November 2001-October 2006 (October-November 2005 missing), MOCAGE January 2000-December 2005, and SLIMCAT January 2000-June 2005. Superimposed are the ECMWF zonal winds, Easterlies (Westerlies) in solid (dashed) lines. Intervals are $5 \mathrm{~m} \mathrm{~s}^{-1}$. The thick solid line represents $0 \mathrm{~m} \mathrm{~s}^{-1}$.

gradient-expansion algorithm to compute a non-linear leastsquare fit of the non-linear function representing the $\mathrm{AO}$, $\mathrm{SAO}$ and QBO. The period under consideration was from November 2001 to June 2005, and the QBO period fixed to 28.2 months. The correlation coefficients between $\mathrm{N}_{2} \mathrm{O}$ concentrations and ECMWF zonal and vertical winds calculated from the integration of the mass-conservative continuity equation are displayed in Tables 1 and 2, respectively. The vertical winds presented in Table 2 are identical to those used by MOCAGE.

\subsection{Mid-to-upper stratosphere (32-1 hPa)}

In the mid-to-upper stratosphere, the three oscillations (AO, SAO and QBO) compete in the ODIN observations, the AO and SAO dominating in the upper stratosphere $(5-1 \mathrm{hPa})$ and the QBO in the middle stratosphere $(32-5 \mathrm{hPa})$. A strong AO signal is seen from 22 to $1 \mathrm{hPa}$ with a broad maximum at around $4.6 \mathrm{hPa}$ of $\sim 15 \mathrm{ppbv}$. As shown by Schoeberl et al. (2008), the AO signal results from the annual variation of the vertical velocity in the lower stratosphere. The correlation $r$ between $\mathrm{N}_{2} \mathrm{O}$ and vertical winds is moderately high, i.e. $0.53-0.66$ between $21-2.1 \mathrm{hPa}$.

A strong SAO signal is observed in the upper stratosphere with marked positive anomalies occurring every two years in 2002, 2004 and 2006. As already noted by Schoeberl et al. (2008) and Jin et al. (2008), the positive (negative) anomalies in the upper stratosphere SAO cycle are in phase with westerly (easterly) QBO phases in the middle stratosphere. The SAO contribution is significant from 10 to $1.5 \mathrm{hPa}$ with a maximum of about $15 \mathrm{ppbv}$ at $4.6 \mathrm{hPa}$.

A QBO signal also appears in the middle stratosphere with a downward propagation of positive (negative) $\mathrm{N}_{2} \mathrm{O}$ anomalies associated with easterly (westerly) phases. The QBO cycle is known to originate in the momentum deposition produced by the damping in the stratosphere of several waves (Rossby, Kelvin, gravity waves, etc.), excited by diabatic 


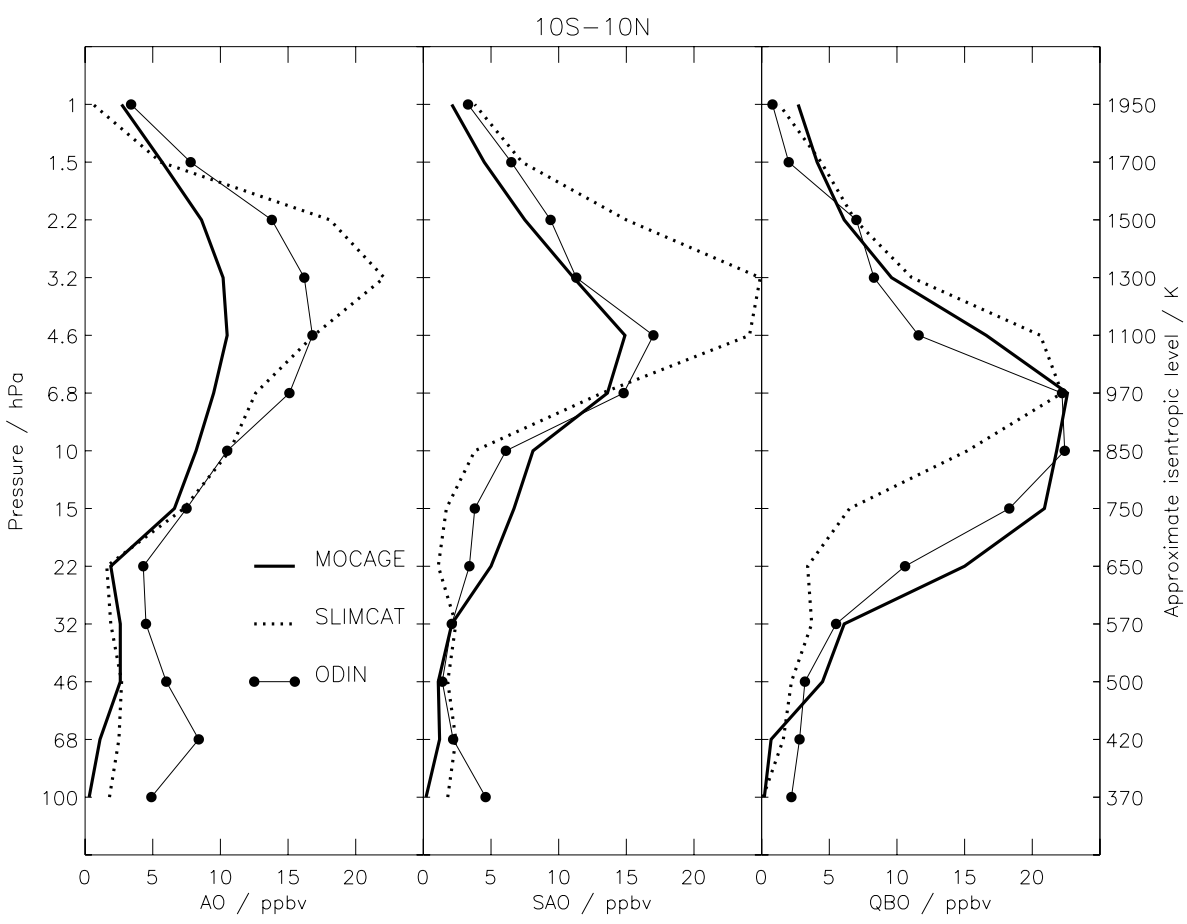

Fig. 2. From left to right: contribution of annual oscillation (AO), semi-annual oscillation (SAO) and quasi-biennial oscillation (QBO) within $10^{\circ} \mathrm{N}-10^{\circ} \mathrm{S}$ for ODIN (filled circles), SLIMCAT (dashed line) and MOCAGE (solid line).

thermal processes in the troposphere (e.g. Cariolle et al., 1993). The QBO easterly (westerly) phase at $40 \mathrm{hPa}$ is associated with an upward (downward) mean meridional circulation bringing $\mathrm{N}_{2} \mathrm{O}$-rich (-poor) air upward (downward). Since easterlies are stronger and last longer than westerlies, the positive $\mathrm{N}_{2} \mathrm{O}$ anomaly in the data also lasts longer than the negative anomaly with a downward propagation from 4.6 to $21 \mathrm{hPa}$ consistent with model calculations of $1 \mathrm{~km}$ month $^{-1}$. Around $20-30 \mathrm{hPa}$ and below, the westerly wind regime propagates downward at constant velocity with little variation between cycles, whilst the descent speed of easterlies slows down at lower altitude (Kinnersley and Pawson, 1996). Because of the stalling of easterlies, the time between maximum easterlies and maximum westerlies is much shorter than the reverse (Naujokat, 1986). This explains the asymmetric descent rates of easterly and westerly regimes seen in the $\mathrm{N}_{2} \mathrm{O}$ concentration with positive anomalies lasting longer than negative ones in the lower stratosphere. The QBO signal extends from 32 to $1 \mathrm{hPa}$ with a maximum amplitude of $\sim 20 \mathrm{ppbv}$ peaking at $10 \mathrm{hPa}$. The anti-correlation $r$ between $\mathrm{N}_{2} \mathrm{O}$ data and zonal winds is indeed very high (0.60-0.74) between 21 and $1 \mathrm{hPa}$.

The two CTMs globally match the data above $32 \mathrm{hPa}$ to within \pm 5 ppbv as well as the amplitude of the AO, SAO and QBO signals (Fig. 2), in contrast to the CMAM chemistryclimate model (Jin et al., 2008), which cannot capture the QBO structure. Nevertheless, some significant differences from the observations are also apparent. The SLIMCAT AO signal is consistent with that of ODIN, but MOCAGE underestimates its amplitude by $5-10 \mathrm{ppbv}$ between 2.2 and $6.8 \mathrm{hPa}$. The SLIMCAT SAO is $10-15 \mathrm{ppbv}$ larger than that observed between 2.2 and $4.6 \mathrm{hPa}$, which is better matched by MOCAGE. Finally, the QBO is very well reproduced by MOCAGE, whereas SLIMCAT underestimates its amplitude by $10-15$ ppbv between 10 and $20 \mathrm{hPa}$.

However, most remarkable (Fig. 2) is the amplitude of the differences between the two models of the same order of magnitude as those between models and observations. Although the slightly different horizontal resolution between the two $\left(7.5^{\circ} \times 7.5^{\circ}\right.$ for SLIMCAT and $5.6^{\circ} \times 5.6^{\circ}$ for MOCAGE) may contribute, the major difference likely results in their method for calculating the vertical advection, forced by ECMWF analyses in MOCAGE and derived from diabatic heating rates in SLIMCAT. The anti-correlation between $\mathrm{N}_{2} \mathrm{O}$ and zonal winds (Table 1) is indeed very high (0.55-0.75) in MOCAGE and SLIMCAT between 10 and $1 \mathrm{hPa}$, as observed. However, the correlation between $\mathrm{N}_{2} \mathrm{O}$ and vertical winds (Table 2) between 2.1 and $10 \mathrm{hPa}$ is rather low in SLIMCAT (0.22-0.50) whilst in MOCAGE the correlation is greater (0.37-0.59) and somewhat more consistent, although smaller than with the ODIN values $(0.53-0.56)$. Since $\mathrm{N}_{2} \mathrm{O}$ from the two models is correlated with the vertical winds used by MOCAGE, we can expect that the correlation is greater in MOCAGE than in SLIMCAT. But once again, this illustrates the importance of vertical advection in the control of the vertical distribution of chemical species in 


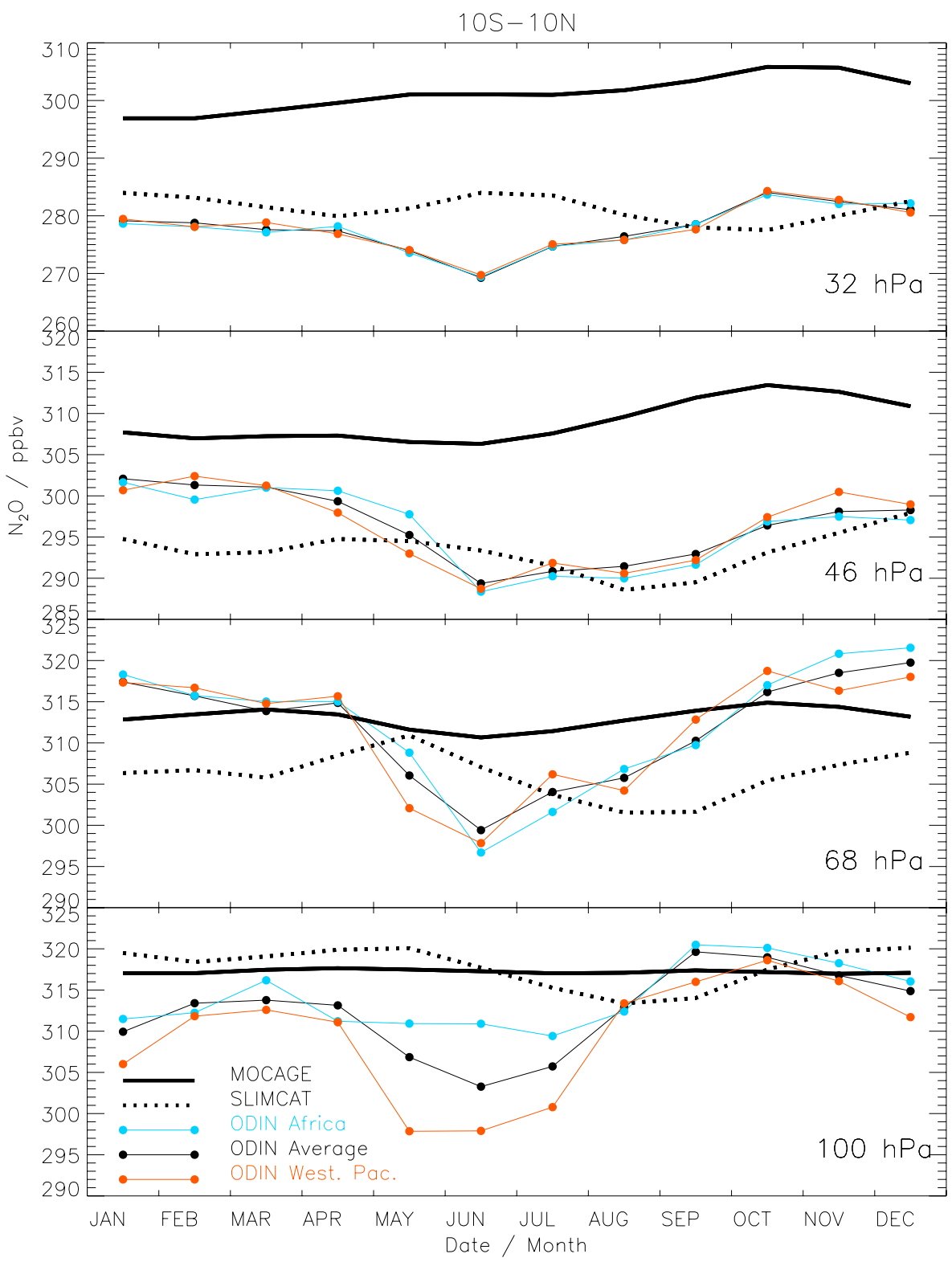

Fig. 3. From bottom to top: $\mathrm{N}_{2} \mathrm{O}$ seasonal variations at $100,68,47$ and $32 \mathrm{hPa}$ within $10^{\circ} \mathrm{S}-10^{\circ} \mathrm{N}$. ODIN zonal mean (black filled circles), over Africa (blue filled circles) and over the Western Pacific (red filled circles), MOCAGE zonal mean (thick solid line) and SLIMCAT zonal mean (dotted line).

the stratosphere, but also the difficulty of reproducing these small vertical velocities in models.

\subsection{UTLS (100-32 hPa)}

At altitudes below $32 \mathrm{hPa}$, the $\mathrm{AO}$ dominates in the observations, except at $100 \mathrm{hPa}$ where a $\mathrm{SAO}$ signal of lesser magnitude can also be seen. Compared to this, the AO is almost missing in the models, whilst the SAO is underestimated at levels below $68 \mathrm{hPa}$. In contrast with the models displaying correlation between $\mathrm{N}_{2} \mathrm{O}$ concentration and ECMWF ver- tical advection (0.69 in SLIMCAT at $100 \mathrm{hPa}$, and 0.61 in MOCAGE at $46 \mathrm{hPa}$ ), the observed variations are disconnected from these. The inability of the models to reproduce the observations suggests that other mechanisms, not or poorly included in the model schemes, are controlling the $\mathrm{N}_{2} \mathrm{O}$ cycle at these levels.

\section{Annual oscillation in the UTLS}

To explore the possible reasons for the large AO signal in the observations below $32 \mathrm{hPa}$, missed by the models, the $\mathrm{N}_{2} \mathrm{O}$ 


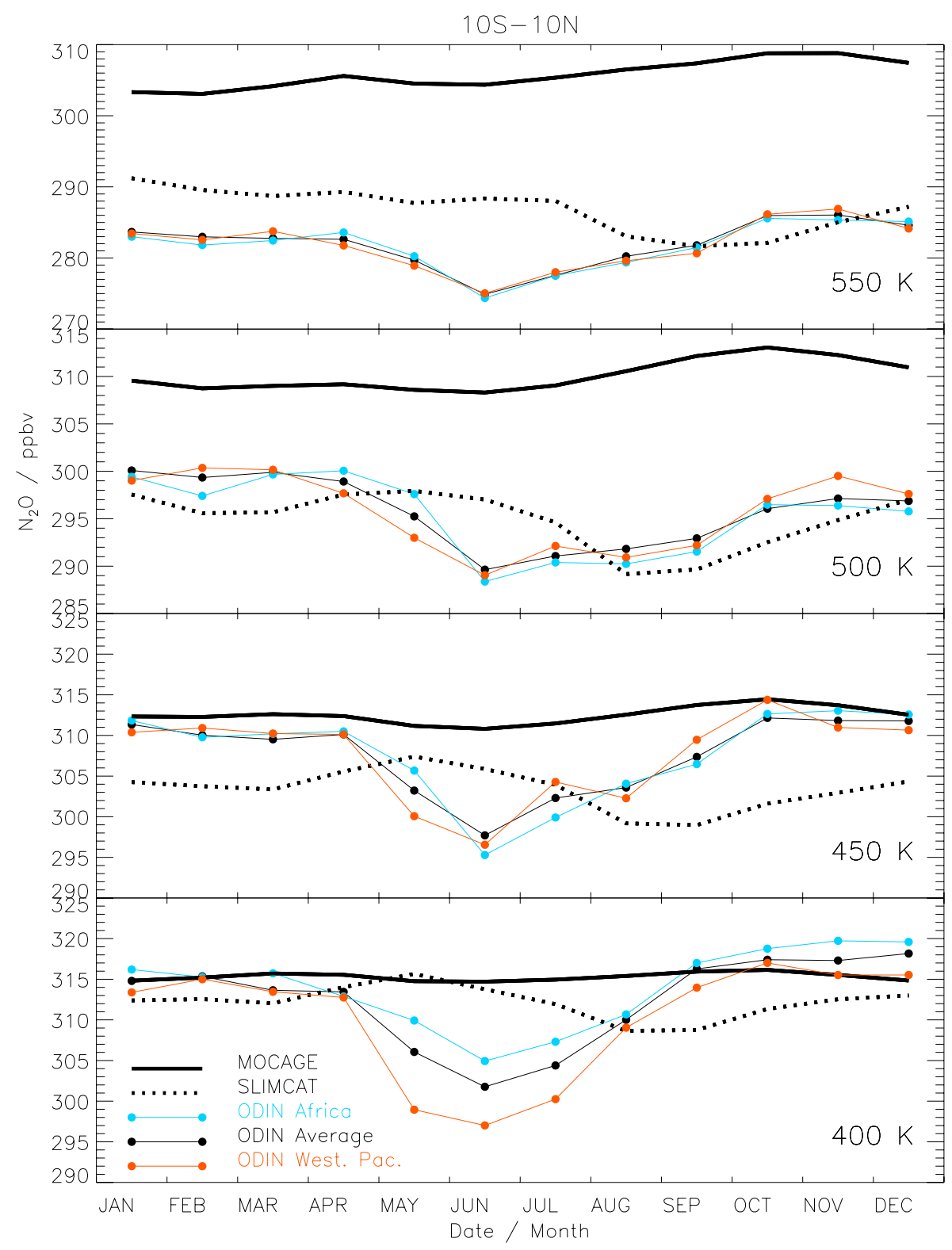

Fig. 4. Same as Fig. 3 but after interpolation on 400, 450, 500 and $550 \mathrm{~K}$ isentropic levels.

mean seasonal variations have been investigated in more detail. Figure 3 displays the seasonal cycle of observed and modelled monthly mean $\mathrm{N}_{2} \mathrm{O}$ concentration at 100, 68, 46 and $32 \mathrm{hPa}$, the levels of the ODIN/SMR measurements, averaged between November 2001 and June 2005. To identify possible geographic differences in the observations such as those reported by Ricaud et al. (2007), also shown are the mean concentrations over the African $\left(30^{\circ} \mathrm{W}-60^{\circ} \mathrm{E}\right)$ and the Western Pacific $\left(120^{\circ} \mathrm{E}-150^{\circ} \mathrm{W}\right)$ sectors. For subtracting the contribution of the well-known seasonal cycle of isentropic surface height on which the mixing ratio would remain constant if no diabatic vertical transport was involved, the $\mathrm{N}_{2} \mathrm{O}$ fields have been linearly interpolated onto potential tempera- ture surfaces. Figure 4 shows the seasonal variations of $\mathrm{N}_{2} \mathrm{O}$ fields interpolated to 400, 450, 500 and $550 \mathrm{~K}$ and Fig. 5 the contrast between the African and Western Pacific sectors. Note that ODIN and MOCAGE only are represented in Fig. 5 since monthly zonally-averaged fields only are available for SLIMCAT. Figure 6 shows the seasonal cycles of tropopause temperature and pressure from the National Centre for Environmental Prediction (NCEP), upwelling from thermodynamic balance from Randel et al. (2007), and potential temperature changes between 15 and $23 \mathrm{~km}$. The minimum height and maximum temperature of the tropopause, the maximum potential temperature at levels above $19 \mathrm{~km}$ and the minimum upwelling are all occurring in July-August. 


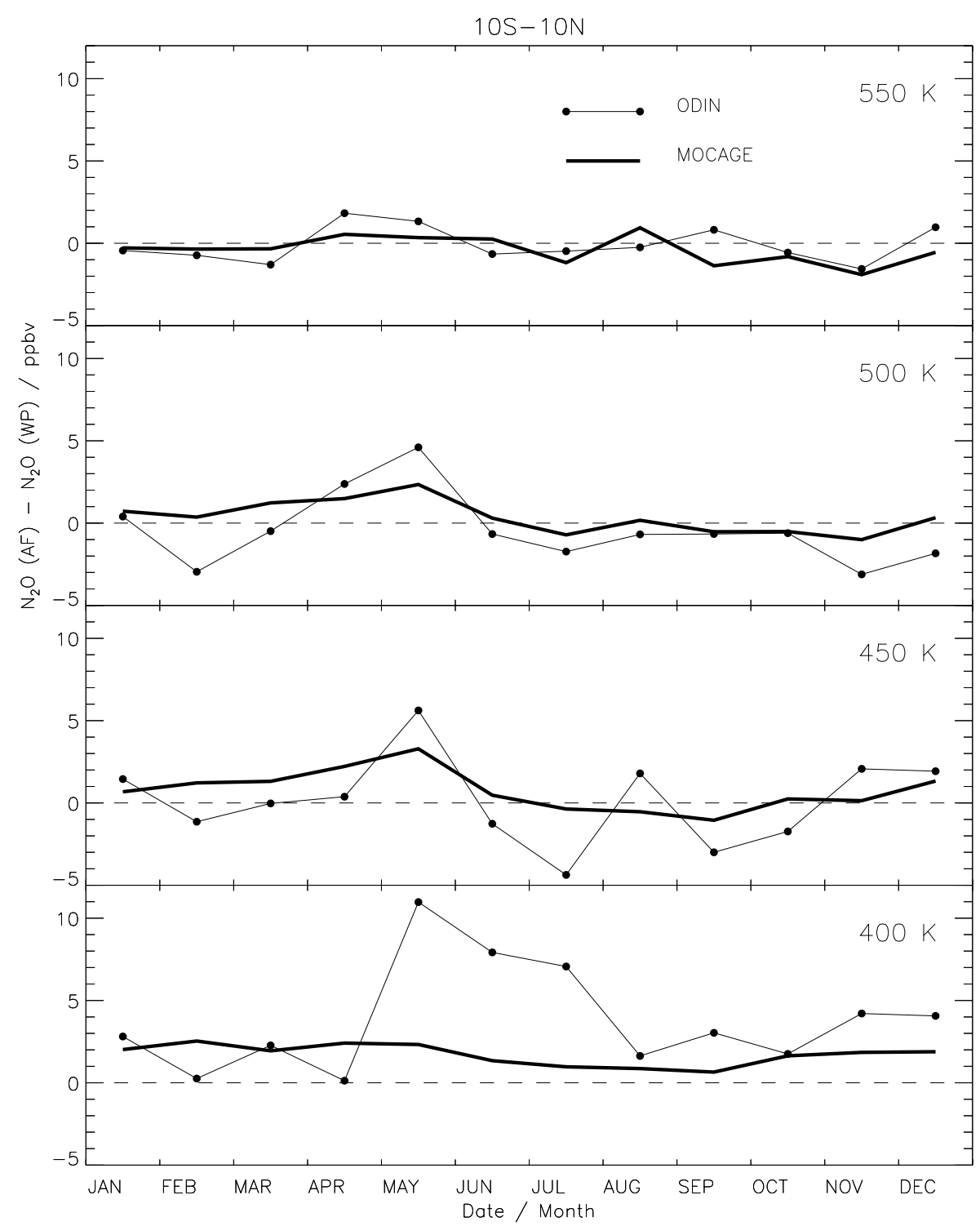

Fig. 5. From bottom to top: $\mathrm{N}_{2} \mathrm{O}$ concentration difference (Africa - Western Pacific) at 400, 450, 500 and $550 \mathrm{~K}$. ODIN (black filled circles) and MOCAGE (thick solid line).

Note that, as already shown by several studies (e.g. MongeSanz et al., 2007), the vertical transport of tracers calculated by a pressure-coordinate model such as MOCAGE is faster than that derived by a sigma-theta coordinate model using a radiation scheme such as SLIMCAT.

\subsection{Seasonal cycle}

An annual cycle is observed in the ODIN $\mathrm{N}_{2} \mathrm{O}$ zonal mean (black dots) at all levels in the lower stratosphere with a minimum between May and August (Figs. 3 and 4) at $400 \mathrm{~K}$ $(\sim 18 \mathrm{~km})$ (Fig. 4), extending to September at all levels above $450 \mathrm{~K}$. Its amplitude is the largest ( $\sim 14 \mathrm{ppbv})$ at the two lowermost layers, 400 and $450 \mathrm{~K}$ reducing to $8-10 \mathrm{ppbv}$ at
$550 \mathrm{~K}$. The minimum $\mathrm{N}_{2} \mathrm{O}$ in June is consistent with that derived by Jin et al. (2009) from the same ODIN observations between July 2001 to February 2007 using the Swedish algorithm version 2.1, as well as from those of AURA/MLS, although the broader MLS vertical resolution results in a weaker contrast. A small semi-annual oscillation with a secondary minimum in January can also be seen at $100 \mathrm{hPa}$ in pressure coordinates in Fig. 3, which disappears in the potential temperature plots of Fig. 4 thus attributed to the zonal and seasonal variation of tropopause height.

There is no time lag between the minimum which always occurs in June at all altitudes up to $550 \mathrm{~K}(22.5 \mathrm{~km})$ or $32 \mathrm{hPa}$ $(24 \mathrm{~km})$, that is no indication of a tape-recorder type signature such as has seen in the HALOE water vapour at higher 


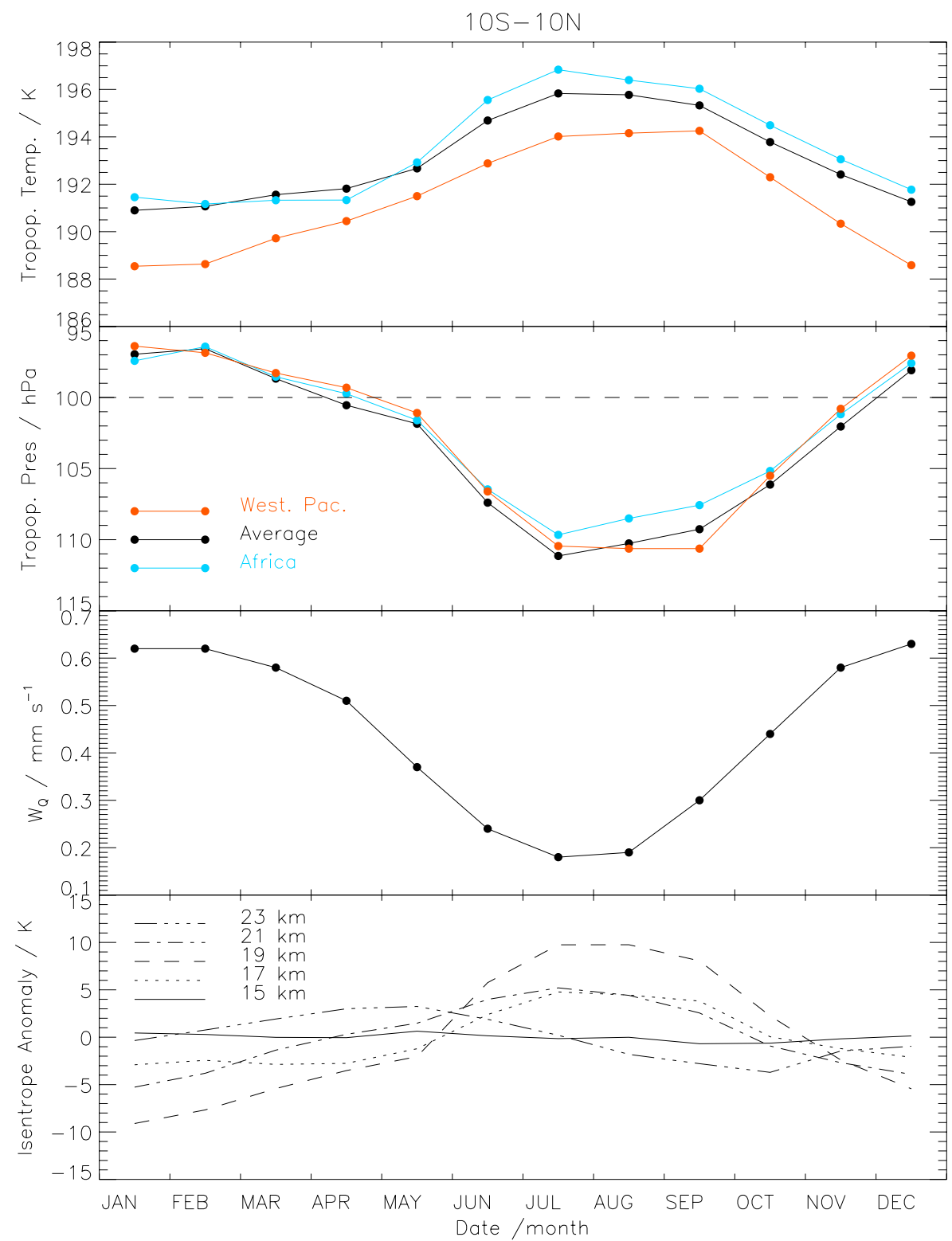

Fig. 6. From top to bottom: NCEP seasonal variation of tropopause temperature, (zonal mean in black, Western Pacific in red, Africa in blue), NCEP tropopause pressure, upwelling calculated from thermodynamic balance (adapted from Randel et al., 2007) and ECMWF potential temperature anomalies between 15 and $23 \mathrm{~km}$.

altitude in the stratosphere, meaning that the minimum propagates upward far faster than the $0.2-0.3 \mathrm{~km} \mathrm{month}^{-1}$ of the Brewer-Dobson upwelling in the $20-25 \mathrm{~km}$ altitude range (Mote et al., 1996). The absence of $\mathrm{N}_{2} \mathrm{O}$ phase shift with altitude in the lower stratosphere was also noticed by Schoeberl et al. (2008) in the MLS data, suggesting that the annual cycle is thus driven by the seasonal variation of the Brewer-Dobson upward velocity. However, since the minimum $\mathrm{N}_{2} \mathrm{O}$ occurs in June, one-two months before the minimum upwelling in July (Randel et al., 2007, and Fig. 6), this explanation is little consistent with the observations.
But most important for understanding the mechanism responsible for the $\mathrm{AO}$ is the zonal modulation of the amplitude of the $\mathrm{N}_{2} \mathrm{O}$ annual cycle, the drop in concentration at $400 \mathrm{~K}$ $(18 \mathrm{~km})$ in May-July being twice larger above the Western Pacific than above Africa. However, this zonal contrast diminishes at higher altitude where it could be observed in May only (Fig. 5).

Compared to the observations, the two models show little seasonal variation. SLIMCAT is displaying a slight minimum in August-September, but given the assumed wellmixed troposphere, this annual cycle of limited amplitude 


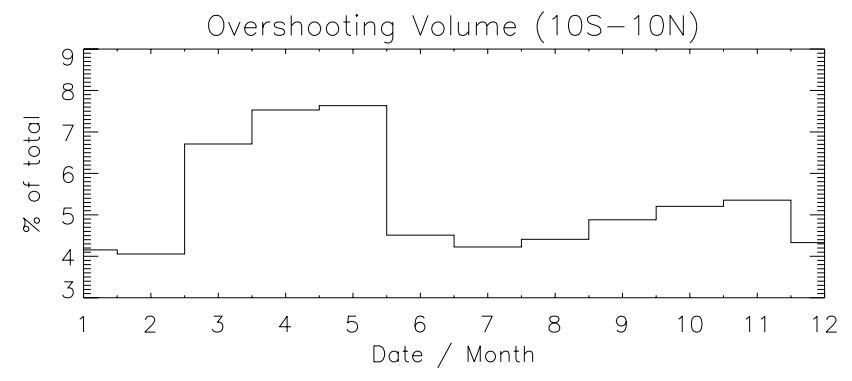

Fig. 7. Seasonal variation of overshooting volume within $10^{\circ} \mathrm{S}-$ $10^{\circ} \mathrm{N}$ from TRMM Overshooting Precipitation Features (OPFs) above $14 \mathrm{~km}$ (in \% unit) (adapted from Liu and Zipser, 2005).

reflects the varying altitude of the tropopause. MOCAGE also shows almost no seasonal variation but the well-known ECMWF too fast ascent of the Brewer-Dobson circulation above $21 \mathrm{~km}$ (Monge-Sanz et al., 2007, and references therein). The same applies to the Canadian Middle Atmosphere Model (CMAM) used by Jin et al. (2009) which underestimates the amplitude of the minimum $\mathrm{N}_{2} \mathrm{O}$ at these levels. The $\mathrm{N}_{2} \mathrm{O}$ seasonal cycle in the lower stratosphere reported by ODIN requires processes not currently captured by the CTM global models.

\subsection{Discussion}

The question is thus: what could be these mechanisms?

\subsubsection{Possible contributions}

Ignoring here the specific issue of $\mathrm{H}_{2} \mathrm{O}$ which involves still unresolved questions of hydration-dehydration processes, the presence of an annual cycle in the concentration of chemical species of relatively long lifetime including $\mathrm{O}_{3}$, in the tropical UTLS has been already noted by Folkins et al. (2006), Randel et al. (2007), Jin et al. (2009), and Schoeberl et al. $(2006,2008)$. The AO is generally attributed to the annual cycle of the vertical upwelling. However, there are differences in the phase of the AO between the species as well as with the upwelling implying contributions from other processes. $\mathrm{An}_{3}$ annual cycle is observed in the tropics of maximum amplitude at $17.5 \mathrm{~km}$ with a minimum concentration in February-March and a maximum in August-September, whilst a CO cycle is reported from the MLS measurements at $68 \mathrm{hPa}(18 \mathrm{~km})$ displaying a maximum in March-April and a minimum in September-October (Randel et al., 2007). Compared to these, $\mathrm{N}_{2} \mathrm{O}$ at the same level displays an almost constant mixing ratio from October to April and a minimum in May-September.

Several mechanisms could contribute to such AOs whose impacts will depend on the vertical gradient of the species. First, when looking at measurements at constant pressure or altitude levels, is the annual cycle of tropical upwelling and vertical displacement of potential temperature levels and tropopause height (Fig. 6). The amplitude of variation of concentration of the species at a given altitude will depend on its vertical gradient at this level. It will be positive and large for $\mathrm{O}_{3}$ for which a vertical downward displacement of only $300 \mathrm{~m}$ within a vertical gradient of $0.8 \mathrm{ppmv} \mathrm{km}^{-1}$ could explain the $0.25 \mathrm{ppmv}$ amplitude of the $\mathrm{AO}$ at $68 \mathrm{hPa}$ $(17.5 \mathrm{~km})$ seen by Randel et al. (2007). It will be negative and smaller for $\mathrm{CO}$ for which the same displacement within

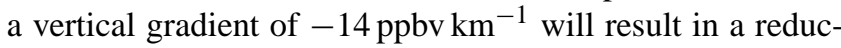
tion of only $3.5 \mathrm{ppbv}$ at the same altitude, and even smaller for $\mathrm{N}_{2} \mathrm{O}$ since a vertical gradient of -6 ppbv $\mathrm{km}^{-1}$ will only produce a $1.5 \mathrm{ppbv}$ change in the lower stratosphere, about 10 times less than that observed.

A second potential contributor is the meridional isentropic exchange with the mid-latitude following the reduced intensity of the subtropical jets in the summer alternatively in the Northern and Southern Hemisphere. But since the CTM models forced by ECMWF known to well representing horizontal transport are not showing significant indication of such process (Fig. 4), the ODIN observed $\mathrm{N}_{2} \mathrm{O}$ minimum cannot be explained by this.

A third contributing parameter is the seasonal cycle of the concentration of the species in the upper troposphere (UT) resulting from sources variations at the surface, chemical processes (e.g. lightning $\mathrm{NO}_{\mathrm{x}}$ ) and convective lifting. In the case of $\mathrm{O}_{3}$, the seasonal change in the tropical UT is limited to 30-40 ppbv, maximum at $15 \mathrm{~km}$ (Randel et al., 2007), which therefore cannot explain the $150 \mathrm{ppbv} \mathrm{AO}$ amplitude at $17.5 \mathrm{~km}$. The $\mathrm{CO}$ variation at $147 \mathrm{hPa}$ shows a small ( 5 ppbv) AO but a larger SAO of 25 ppbv amplitude with minima in December-February and July-September (Randel et al., 2007). In contrast to $\mathrm{O}_{3}$, the $\mathrm{CO}$ sources at the surface are highly variable and zonally contrasted resulting in large variations of the species in the UT, mostly semi-annual of $25 \mathrm{ppbv}$ amplitude in the tropics, which could then contribute significantly to the $15 \mathrm{ppbv}$ AO amplitude reported by MLS at $68 \mathrm{hPa}$ (Schoeberl et al., 2006; Randel et al., 2007). But this hardly applies to $\mathrm{N}_{2} \mathrm{O}$, for which a model like MOCAGE, including the geographic distribution and variability of its sources at the surface, is displaying an annual cycle of less than $1.5 \mathrm{ppbv}$ amplitude at $400 \mathrm{~K}$. Although recent measurements from the Infrared Atmospheric Sounding Interferometer (IASI) instrument aboard the MetOp-A platform indicate an $\mathrm{N}_{2} \mathrm{O}$ total tropospheric column in MAM larger by $1.6 \%$ (instead of $0.8 \%$ for MOCAGE) over Africa than the Pacific attributed to the Walker circulation (Ricaud et al., 2009), unless the seasonal and geographic variations of the sources are strongly underestimated in the model, it is difficult to see how this could explain a 15 ppbv $\mathrm{N}_{2} \mathrm{O}$ seasonal amplitude.

A fourth potential contributor to the $\mathrm{AO}$ cycle is the fast convective overshooting of tropospheric air above continental regions and particularly Africa, between February and May and, to a lesser extent, in September-November as shown by the overshooting volume in the $10^{\circ} \mathrm{S}-10^{\circ} \mathrm{N}$ band 
(Fig. 7) derived from the TRMM precipitation radar overshooting features (Liu and Zipser, 2005). This mechanism was that suggested by Ricaud et al. (2007) for explaining the contrast in $\mathrm{N}_{2} \mathrm{O}, \mathrm{CH}_{4}$ and $\mathrm{CO}$ concentrations in the lower stratosphere between the Western Pacific, Africa and other continental areas. However, the amplitude of the contrast between various regions will also depend on the zonal wind velocity that is the time needed for local injections in preferred regions to mix at zonal scale.

At last, a fifth potential contributor could be the existence of sinking regions in the lower stratosphere, like above Indonesia as shown by Sherwood (2000), required for closing the energy budget following the overshooting irreversible injection of cold and heavy air at great heights known to occur over land (Pommereau and Held, 2007). Resulting in the subsidence of stratospheric air, this process might result in the depletion of the concentration of tropospheric constituents in the UTLS above specific regions during intense convective periods.

The seasonal cycle of each species will be a combination of all these parameters whose impacts will depend on the characteristics, i.e. vertical gradient and photochemical lifetime, specific to each species.

\subsubsection{Ozone}

Because of its maximum vertical gradient at $17.5 \mathrm{~km}$, the $\mathrm{O}_{3}$ $\mathrm{AO}$ at constant altitude (Randel et al., 2007) in phase with the seasonal variation of temperature is dominated by the variation of mean upwelling resulting in the vertical displacement of the tropopause and isentropic surfaces heights by almost one kilometre in July-September (Fig. 6). Although convective overshooting of tropospheric ozone poor air could also contribute as shown by the differences between the different Southern Hemisphere Additional Ozonesondes (SHADOZ) stations during the period of minimum $\mathrm{O}_{3}$ in February-April (Randel at al., 2007), its impact is very limited compared to that of the uplift of the layer. Another feature difficult to explain by considering upwelling process only is the time shift by up to two months between the temporal locations of the maximum at different ozonesonde stations.

\subsubsection{Carbon monoxide}

The MLS CO shows two maxima in the tropical upper troposphere related to biomass burning activity, in OctoberDecember above South America and in February-May above Africa (Schoeberl et al., 2006). However, the CO seasonal cycle at $68 \mathrm{hPa}$ (Randel et al., 2007) displays a single maximum in February-April like if the large November CO tropospheric burden was not lofted above the tropopause, in contrast to the second in February-April reaching higher altitude. Since a slow vertical displacement will have limited impact on the concentration of the species given the 4-month lifetime of the species at these levels (Randel et al., 2007), the observations will be better compatible with overshooting to high altitude during the convective season in February-April, followed by a relatively fast photochemical reduction during the following 5 months. Overshoot episodes, such as those reported by Ricaud et al. (2007) over Africa, could also explain the fast anti-correlated $\mathrm{CO}-\mathrm{O}_{3}$ changes at $68 \mathrm{hPa}$ shown by MLS (Randel et al., 2007), which would require vertical velocities exceeding the slow upwelling velocity (Folkins et al., 2006; Corti et al., 2005).

\subsubsection{Nitrous oxide}

At constant pressure levels, $\mathrm{N}_{2} \mathrm{O}$ (Fig. 3) displays a zonal mean seasonal cycle with a minimum in May-July of $15 \mathrm{ppbv}$ amplitude at $100 \mathrm{hPa}$, increasing to $20 \mathrm{ppbv}$ at $68 \mathrm{hPa}(19 \mathrm{~km})$, and then reducing progressively at higher al-

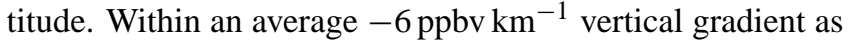
observed by ODIN at least above $68 \mathrm{hPa}$, this would correspond to a vertical displacement of $2.5,3.3,2.0$ and $1.7 \mathrm{~km}$ at $100,68,46$ and $32 \mathrm{hPa}$, respectively. After interpolation on isentropic surfaces for correcting the seasonal variation of the isentropic surface height (Fig. 4), the amplitude is slightly reduced particularly the September-October maximum at $400 \mathrm{~K}$ and that of November-December at $450 \mathrm{~K}$, thus removing the SAO signal. But since this minimum is out of phase by 2 months with the minimum upwelling calculated from thermodynamic balance (Randel et al., 2007), it cannot be attributed to this only.

But most remarkable is the zonal contrast between the Western Pacific and Africa (Fig. 5), maximum in May-July at $400 \mathrm{~K}$, but limited to May only at 450 and $500 \mathrm{~K}$ and disappearing at $550 \mathrm{~K}$, which coincides with the maximum overshooting volume of the TRMM precipitation radar (Fig. 7) and the minimum mean zonal wind velocity (Fig. 8).

More insight on possible mechanisms responsible for that is given by the evolution of the monthly mean $\mathrm{N}_{2} \mathrm{O}$ vertical profiles (Fig. 9). The highest $\mathrm{N}_{2} \mathrm{O}$ concentration at $400 \mathrm{~K}$ and the smallest gradient between 400 and $450 \mathrm{~K}$ with little or no zonal contrast are observed from September to April. The reduction starts suddenly in May at lowest level, first at $400 \mathrm{~K}$, reaching its maximum in June at $500 \mathrm{~K}$. The models completely miss those changes. MOCAGE is showing too fast constant vertical transport throughout the year and SLIMCAT, based on radiative calculations, slower average velocity with a slight minimum in August-September.

The origin of the large drop in $\mathrm{N}_{2} \mathrm{O}$ concentration in June, ignored by the models, is thus unclear. According to TRMM, May is the month of highest overshooting volume. But more intense overshooting would mean larger injection of tropospheric $\mathrm{N}_{2} \mathrm{O}$-rich air and not the opposite since its concentration varies little in the upper troposphere. Another contradiction is the more intense reduction over the Western Pacific than Africa. Indeed, in the middle troposphere $(\sim 10 \mathrm{~km})$ whatever the season considered, MOCAGE shows maxima of $\mathrm{N}_{2} \mathrm{O}$ above Africa and minina above Western 


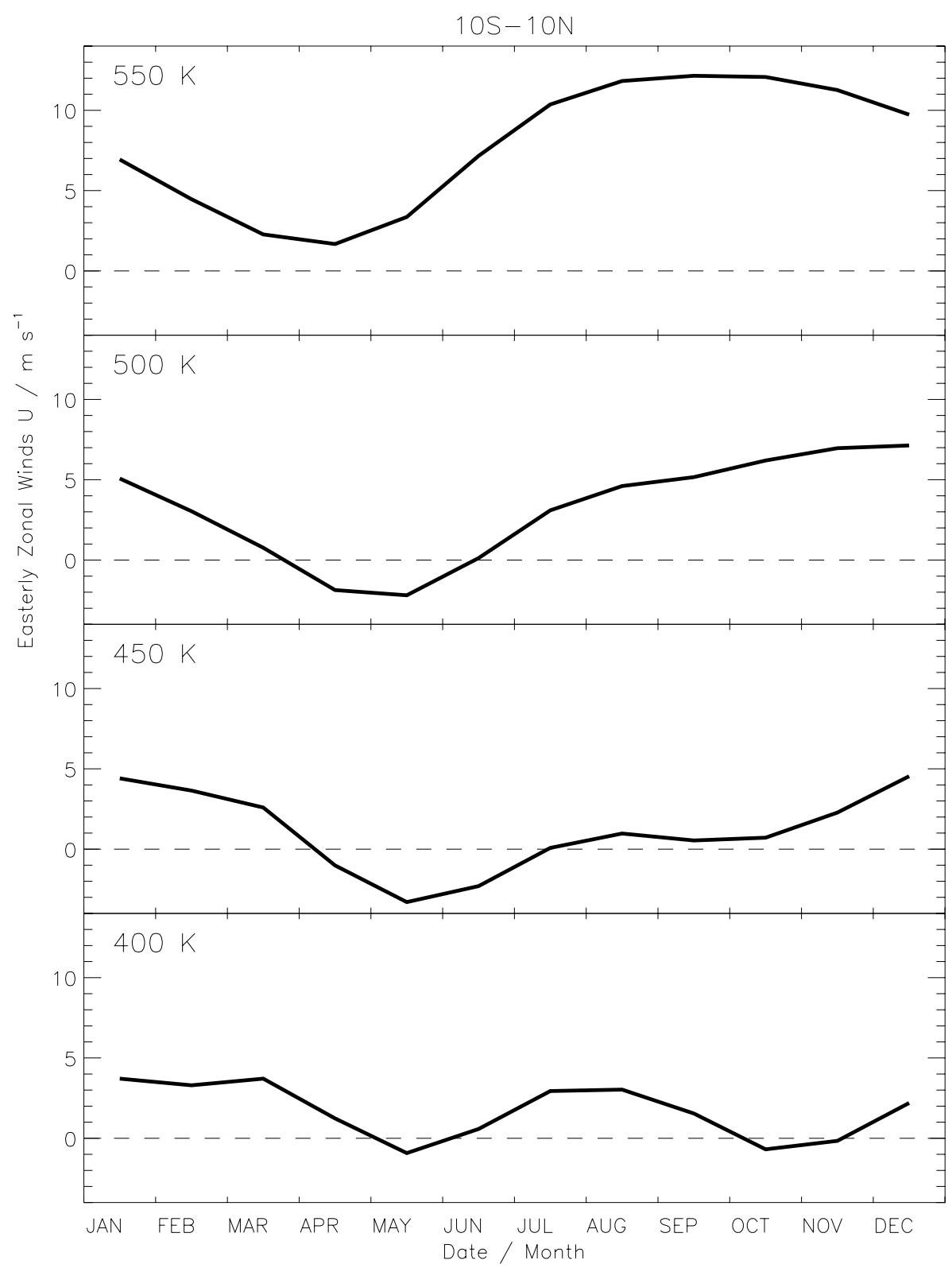

Fig. 8. From bottom to top: Seasonal variation of ECMWF easterly zonal mean wind speed at 400, 450, 500 and $550 \mathrm{~K}$.

Pacific (Fig. 10). The $1.6 \%$ larger $\mathrm{N}_{2} \mathrm{O}$ tropospheric column over Africa than over the Pacific reported by Ricaud et al. (2009) from IASI observations might contribute but is too small for explaining the amplitude of the contrast between the two regions in the lower stratosphere. Unless the assumed geographical and seasonal changes of $\mathrm{N}_{2} \mathrm{O}$ sources at the surface are significantly wrong, this explanation seems contradictory.

Another contributor might be the hypothesis of the existence of localised stratospheric drains, as reported by Sherwood (2000) over Indonesia, that is the subsidence of $\mathrm{N}_{2} \mathrm{O}$ poorer stratospheric air. Such process could also explain the anti-correlation between $\mathrm{CO}$ and $\mathrm{O}_{3}$ fast variations reported by MLS at $68 \mathrm{hPa}$ in the equatorial belt during the convective season, as well as time shifts by up to two months between ozone seasonal maxima at different stations (Randel et al., 2007).

In summary, the observed ODIN $\mathrm{N}_{2} \mathrm{O}$ seasonal cycle in the lower stratosphere, different from those of $\mathrm{O}_{3}$ and $\mathrm{CO}$, themselves not strictly anti-correlated, and the contrast of concentration between the Western Pacific and the African sectors during the most intense convective season, is not consistent with a seasonal modulation of upwelling alone. Unless the current understanding of $\mathrm{N}_{2} \mathrm{O}$ sources at the surface 

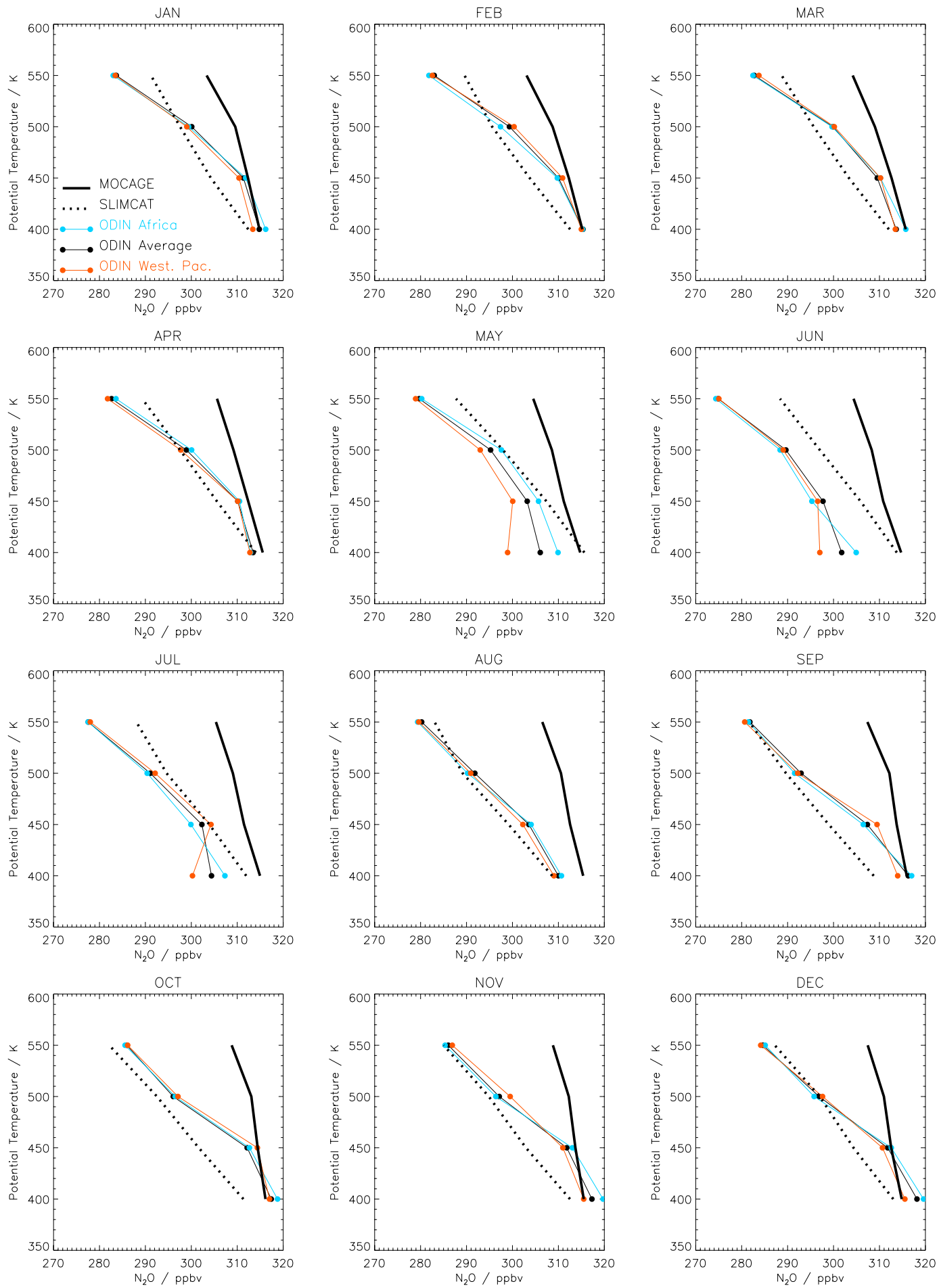

Fig. 9. Monthly mean $\mathrm{N}_{2} \mathrm{O}$ vertical profiles from January to December. ODIN zonal mean (black filled circles), over Africa (blue filled circles) and the West Pacific (red filled circles), MOCAGE (thick solid line) and SLIMCAT (dotted line) zonal mean.

is wrong, it would be better compatible with a combination of subsidence of stratospheric air over localised areas compensating the energy sink resulting from deep overshooting during most intense convective period in May and seasonal variation of the zonal wind displaying a minimum in AprilJune. If this assumption is correct, the $\mathrm{N}_{2} \mathrm{O}$ annual cycle in the lower stratosphere might confirm the hypothesis of the convective origin of the larger $\mathrm{N}_{2} \mathrm{O}$ concentration over Africa 
a) MOCAGE $\mathrm{N}_{2} \mathrm{O}$ FMA
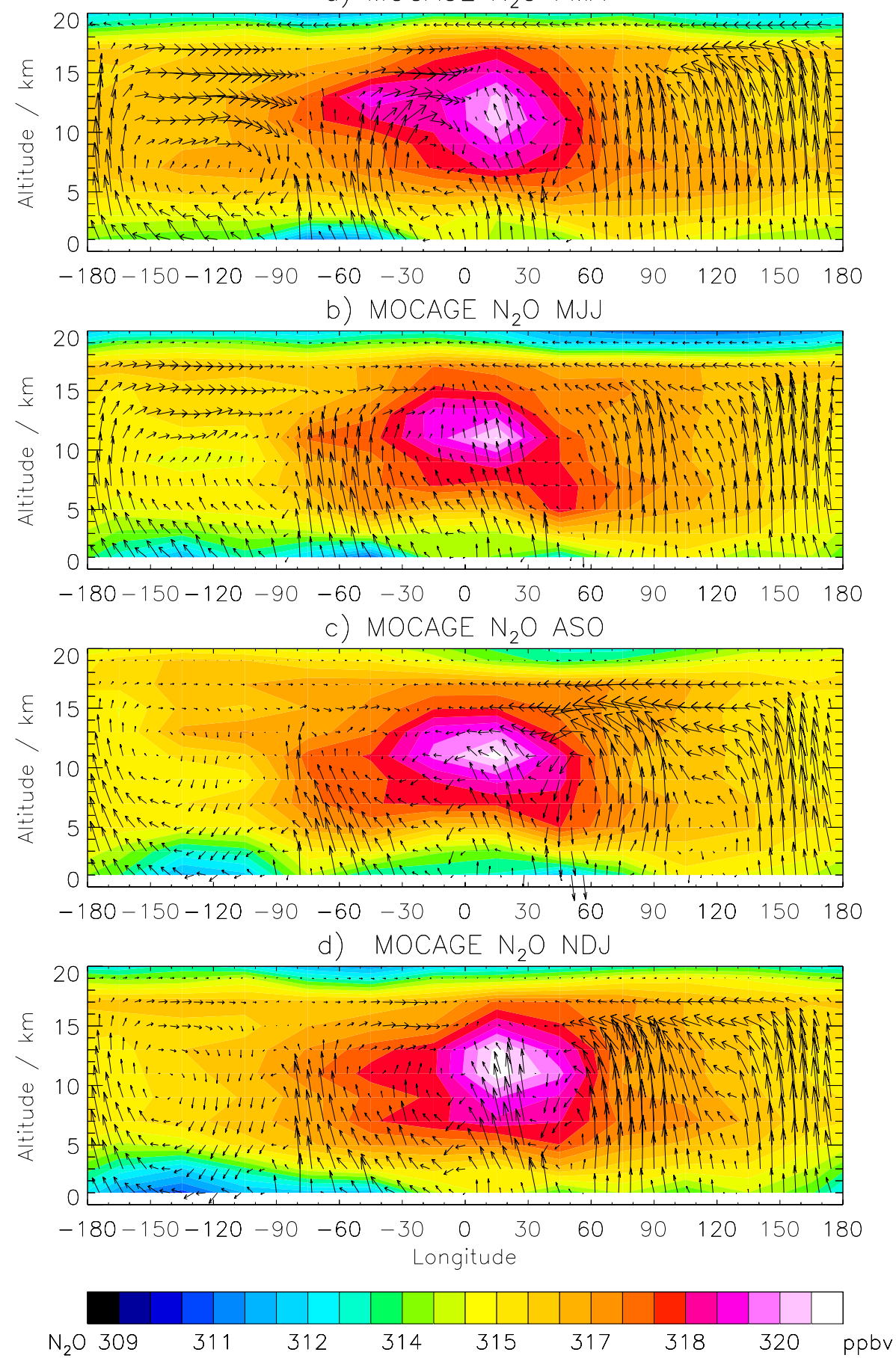

Fig. 10. Mean 2001-2005 MOCAGE $\mathrm{N}_{2} \mathrm{O}$ altitude-longitude cross-section within $10^{\circ} \mathrm{S}-10^{\circ} \mathrm{N}$. From top to bottom: FMA, MJJ, ASO and NDJ. Superimposed are the wind direction and speed where the vertical component is amplified by a factor 100 .

compared to the Western Pacific as reported earlier by Ricaud et al. (2007) and thus the influence of overshooting on the chemical composition of the lower stratosphere at global scale up to $20-21 \mathrm{~km}$ altitude.

\section{Conclusions}

The evolution of the concentration of the long-lived $\mathrm{N}_{2} \mathrm{O}$ species in the stratosphere has been studied from the measurements of the space-borne ODIN/SMR instrument from 
November 2001 to June 2005. The mechanisms responsible for the observed oscillations have been explored by comparing the measurements with simulations of two chemical transport models (CTMs), both forced with ECMWF analyses, where the vertical transport is derived from the forcing analyses by solving the continuity equation (MOCAGE) and from diabatic heating rates using a radiation scheme (SLIMCAT).

The observed $\mathrm{N}_{2} \mathrm{O}$ variations are found influenced by the annual, semi-annual and quasi-biennial oscillations of comparable amplitudes in the mid-stratosphere, whilst the AO dominates below $32 \mathrm{hPa}$ of peak amplitude at $68 \mathrm{hPa}$, and a significant $\mathrm{SAO}$ signature at $100 \mathrm{hPa}$. Both CTMs generally match the observations above $32 \mathrm{hPa}$ to within $\pm 5 \mathrm{ppbv}$ as well as the amplitude of the AO, SAO and QBO signals. However, significant differences appear with the observations as well as between the models, attributed to the difficulty of capturing correctly the slow upwelling of the Brewer-Dobson circulation.

However, the situation is worse in the lower stratosphere where the models, although one of them includes upwelling calculations using a radiative scheme, totally miss the observed $\mathrm{N}_{2} \mathrm{O}$ annual oscillation at this level. The minimum $\mathrm{N}_{2} \mathrm{O}$ in June, moreover amplified over the West Pacific compared to Africa particularly in May, is not compatible with the known minimum seasonal upwelling occurring two months later in August evoked for explaining the ozone seasonal variation in the tropical lower stratosphere. Unless the current understanding of the geographical and seasonal distributions of $\mathrm{N}_{2} \mathrm{O}$ sources at the surface, resulting in little variable $(<1.5 \mathrm{ppbv})$ concentration of the species in the upper troposphere, is totally wrong, the explanation of the observed 15 ppbv amplitude of the $\mathrm{N}_{2} \mathrm{O}$ annual cycle in the lower stratosphere requires another mechanism. A possible candidate for that might be a local downward mass flux above specific regions associated with deep overshooting over intense convective areas combined with the seasonal variation of the zonal horizontal wind. But since global models do currently not capture the subsidence, it is difficult to provide a full explanation of the observations. However, the confirmation of larger $\mathrm{N}_{2} \mathrm{O}$ concentration in the lower stratosphere over Africa compared to the Western Pacific during the convective period reported by Ricaud et al. (2007) suggests a significant influence of convective overshooting and possibly local drains on the chemical composition of the lower stratosphere at the global scale up to $500 \mathrm{~K}(20-21 \mathrm{~km})$.

Acknowledgements. ODIN is a Swedish-led satellite project funded jointly by the Swedish National Space Board (SNSB), the Canadian Space Agency (CSA), the National Technology Agency of Finland (Tekes), and the Centre National d'Etudes Spatiales (CNES). Odin V222 data have been obtained from the ETHER French atmospheric database (http://ether.ipsl.jussieu.fr). The project was funded by the French CNRS-CNES LEFE programme, the SCOUT-O3 and ACCENT AT2 projects of the European Commission which are gratefully acknowledged. The SLIMCAT modelling was supported by the NERC National Centre for Earth Observation (NCEO). We finally would like to thank the two anonymous reviewers for their very fruitful comments.

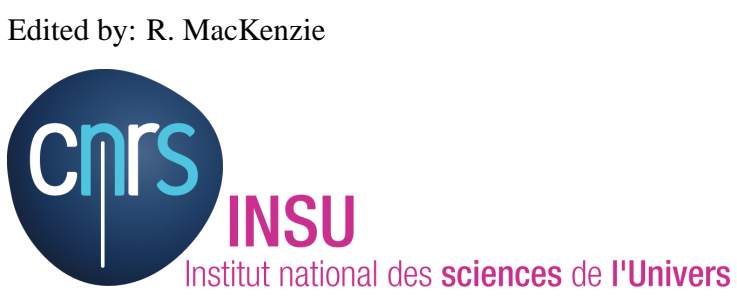

The publication of this article is financed by CNRS-INSU.

\section{References}

Baldwin, M. P., Gray, L. J., Dunkerton, T. J., et al.: The QuasiBiennial Oscillation, Rev. Geophys., 39, 179-229, 2001.

Barret, B., Ricaud, P., Santee, M. L., et al.: Intercomparisons of trace gases profiles from the Odin/SMR and Aura/MLS limb sounders, J. Geophys. Res., 111, D21302, doi:10.1029/2006JD007305, 2006.

Betchold, P., Bazile, E., Guichard, F., et al.: A mass flux convection scheme for regional and global models, Q. J. Roy. Meteorol. Soc., 127, 869-886, 2001.

Bouwman, A. F., Van der Hoek, K. W., and Olivier, J. G. J.: Uncertainties in the global source distribution of nitrous oxide, J. Geophys. Res., 100(D2), 2785-2800, 1995.

Brasseur, G. P., Orlando, J. J., and Tyndall, G. S.: Atmospheric chemistry and global change, 2nd edition, Oxford University Press, New York, Oxford, ISBN-0-19-510521-4, 1999.

Cariolle, D., Amodei, M., Déqué, M., et al.: A quasi-biennal oscillation signal in general circulation model simulations, Science, 261, 1313-1316, 1993.

Chipperfield, M. P.: Multiannual simulations with a threedimensional chemical transport model, J. Geophys. Res., 104, 1781-1805, 1999.

Chipperfield, M. P.: New version of the TOMCAT/SLIMCAT offline chemical transport model: Intercomparison of stratospheric tracer experiments, Q. J. Roy. Meteorol. Soc., 132, 1179-1203, doi:10.1256/qj.05.51, 2006.

Corti, T., Luo, B. P., Peter, T., Vömel, H., and Fu, Q.: Mean radiative energy balance and vertical mass fluxes in the equatorial upper troposphere and lower stratosphere, Geophys. Res. Lett., 32, L06802, doi:10.1029/2004GL021889, 2005.

Feng, W., Chipperfield, M. P., Dorf, M., Pfeilsticker, K., and Ricaud, P.: Mid-latitude ozone changes: studies with a 3-D CTM forced by ERA-40 analyses, Atmos. Chem. Phys., 7, 2357-2369, 2007, http://www.atmos-chem-phys.net/7/2357/2007/.

Folkins, I., Bernath, P., Boone, C., Lesins, G., Livesey, N., Thompson, A. M., Walker, K., and Witte, J. C.: Seasonal cycles of $\mathrm{O}_{3}$, $\mathrm{CO}$ and convective outflow at the tropical tropopause, Geophys. Res. Lett., 33, L16802, doi:10.1029/2006GL026602, 2006.

Frisk, U., Hagström, M., Ala-Laurinaho, J., et al.: The Odin satellite I: Radiometer design and test, Astron. Astrophys., 402(3), L27L34, doi:10.1051/0004 6361:20030335, 2003. 
Gettelman, A., Kinnison, D. E., Dunkerton, T. J., and Brasseur, G. P.: Impact of monsoon circulations on the upper troposphere and lower stratosphere, J. Geophys. Res., 109, D22101, doi:10.1029/2004JD004878, 2004.

Intergovernmental Panel on Climate Change: Climate change 2001: The scientific basis, contribution of working group I to the third Assessment report of the IPCC, edited by: Houghton, J. T., Ding, Y., Griggs, D. J., et al., Cambridge Univ. Press, New York, 2001.

Jin, J. J., Semeniuk, K., Beagley, S. R., et al.: Comparison of CMAM simulations of carbon monoxide (CO), nitrous oxide $\left(\mathrm{N}_{2} \mathrm{O}\right)$, and methane $\left(\mathrm{CH}_{4}\right)$ with observations from Odin/SMR, ACE-FTS, and Aura/MLS, Atmos. Chem. Phys., 9, 3233-3252, 2009 , http://www.atmos-chem-phys.net/9/3233/2009/.

Kinnersley, J. S. and Pawson, S.: The descent rates of the shear zones of the equatorial QBO, J. Atmos. Sci., 53, 1937-1949, 1996.

Liu, C. and Zipser, E. J.: Global distribution of convection penetrating the tropical tropopause, J. Geophys. Res., 110, D23104, doi:10.1029/2005JD006063, 2005.

Monge-Sanz, B. M., Chipperfield, M. P., Simmons, A. J., and Uppala, S. M.: Mean age of air and transport in a CTM: comparison of different ECMWF analyses, Geophys. Res. Lett., 34, L04801, doi:10.1029/2006GL028515, 2007.

Mote, P., Rosenlof, K., Mclntyre, M., Carr, E., Gille, J., Holton, J., Kinnersley, J., Pumphrey, H., Russell III, J., and Waters, J.: An atmospheric tape recorder: The imprint of tropical tropopause temperatures on stratospheric water vapor, J. Geophys. Res., 101(D2), 3989-4006, 1996.

Murtagh, D., Frisk, U., Merino, F., et al.: An overview of the Odin atmospheric mission, Can. J. Phys., 80, 309-319, 2002.

Naujokat, B.: An updated of the observed quasi-biennial oscillation of the stratospheric winds over the Tropics, J. Atmos. Sci., 43, 1873-1877, 1986.

O'Sullivan, D. and Dunkerton, T. J.: The influence of the quasibiennal oscillation on global constituent distributions, J. Geophys. Res., 102, 21731-21743, 1997.

Randel, W. J., Boville, B. A., Gille, J. C., et al.: Simulation of stratospheric $\mathrm{N}_{2} \mathrm{O}$ in the NCAR CCM2: comparison with CLAES data and global budget analysis, J. Atmos. Sci., 51, 2834-2845, 1994.

Randel, W. J. and Wu, F.: Isolation of the ozone QBO in SAGE II data by singular-value decomposition, J. Atmos. Sci., 53, 25462559, 1996.
Randel, W. J., Park, M., Wu, F., and Livesey, N. J.: A large annual cycle in ozone above the tropical tropopause linked to the Brewer-Dobson circulation, J. Atmos. Sci., 64, 4479-4488, doi:10.1175/2007JAS2409.1, 2007.

Ricaud, P., Barret, B., Attié, J.-L., Motte, E., Le Flochmoën, E., Teyssèdre, H., Peuch, V.-H., Livesey, N., Lambert, A., and Pommereau, J.-P.: Impact of land convection on tropospherestratosphere exchange in the tropics, Atmos. Chem. Phys., 7, 5639-5657, 2007,

http://www.atmos-chem-phys.net/7/5639/2007/.

Ricaud, P., Attié, J.-L., Teyssèdre, H., El Amraoui, L., Peuch, V.H., Matricardi, M., and Schluessel, P.: Equatorial total column of nitrous oxide as measured by IASI on MetOp-A: implications for transport processes, Atmos. Chem. Phys., 9, 3947-3956, 2009, http://www.atmos-chem-phys.net/9/3947/2009/.

Rodgers, C. D.: Inverse methods for atmospheric sounding: theory and practice, 1st ed., World Sci., River Edge, N. J., 2000.

Schoeberl, M. R., Duncan, B. N., Douglass, A. R., Waters, J., Livesey, N., Read, W., and Filipiak, M.: The carbon monoxide tape recorder, Geophys. Res. Lett., 33, L12811, doi:10.1029/2006GL026178, 2006.

Schoeberl, M. R., Douglass, A. R., Newman, P. A., et al.: QBO and Annual Cycle Variations in tropical Lower Stratosphere Trace Gases from HALOE and AURA MLS observations, J. Geophys. Res., 113, D05301, doi:10.1029/2007JD008678, 2008.

Teyssèdre, H., Michou, M., Clark, H. L., Josse, B., Karcher, F., Olivié, D., Peuch, V.-H., Saint-Martin, D., Cariolle, D., Attié, J.-L., Nédélec, P., Ricaud, P., Thouret, V., van der A, R. J., VolzThomas, A., and Chroux, F.: A new tropospheric and stratospheric Chemistry and Transport Model MOCAGE-Climat for multi-year studies: evaluation of the present-day climatology and sensitivity to surface processes, Atmos. Chem. Phys., 7, 58155860, 2007, http://www.atmos-chem-phys.net/7/5815/2007/.

Uppala, S. M., Kallberg, P. W., Simmons, A. J., et al.: The ERA40 re-analysis, Q. J. Roy. Meteorol. Soc., 131(612), 2961-3012 (Part B), 2005.

Urban, J., Lautié, N., Le Flochmoën, E., et al.: Odin/SMR limb observations of stratospheric trace gases: Level 2 processing of $\mathrm{ClO}, \mathrm{N}_{2} \mathrm{O}, \mathrm{HNO}_{3}$, and $\mathrm{O}_{3}$, J. Geophys. Res., 110, D14307, doi:10.1029/2004JD005741, 2005.

Yang Q., Fu, Q., Austin, J., Gettelman, A., Li, F., and Vömel, H.: Observationally derived and general circulation model simulated tropical stratospheric upward mass fluxes, J. Geophys. Res., 113, D00B07, doi:10.1029/2008JD009945, 2008. 